\title{
Recoveries of Valuable Metals from Spent Nickel Metal Hydride Vehicle Batteries via Sulfation, Selective Roasting, and Water Leaching
}

\author{
Kivanc Korkmaz ${ }^{1} \cdot$ Mahmood Alemrajabi $^{1} \cdot$ Åke Rasmuson $^{1} \cdot$ Kerstin Forsberg $^{1}$ (1)
}

Published online: 19 March 2018

(C) The Author(s) 2018

\begin{abstract}
The recoveries of rare earth elements (REEs), nickel, and cobalt from hybrid electric vehicle batteries by sulfation, selective roasting, and water leaching have been studied. The cathode and anode materials of a Panasonic Prismatic Module nickel metal hydride (NiMH) battery were used in the study. The optimal conditions for each step of the process were determined by performing lab-scale experiments. It was found that $8 \mathrm{~mol} / \mathrm{L}$ of sulfuric acid was sufficient for the sulfation with a solid-to-liquid ratio of $1 / 5$. The optimal roasting conditions was determined to be $850{ }^{\circ} \mathrm{C}$ for $2 \mathrm{~h}$. Under optimal conditions, $96 \%$ of the REEs could be obtained in the aqueous phase with negligible contamination of Ni and Co. The $\mathrm{Ni}$ and Co remained in solid phase as oxides together with traces of aluminum, zinc, and iron oxides. This method provides a way for the separation of the REEs from nickel, cobalt, and other elements present in the NiMH battery, into a leachate suitable for further processing.
\end{abstract}

Keywords Hydrometallurgy $\cdot$ Rare earth recovery $\cdot$ Selective roasting $\cdot$ NiMH battery recycling

\section{Introduction}

Nickel metal hydride (NiMH) batteries are commonly used in many applications in our daily life. They are available in many sizes and forms from AA batteries to all-electric plug in vehicles in hybrid electric vehicle (HEV) applications. The big companies in the automobile industry, such as Toyota, Honda, Ford, and Chevrolet have been using NiMH batteries in their HEVs since the early 1980s. Upon the end of the batteries life cycle, the need to recycle them has been gaining importance. A NiMH battery is a source of rare earth elements (REEs) as well as of nickel and cobalt. The European Commission has declared REEs as critical elements due to their supply risk where Asia is dominating the market [1]. Moreover, to decrease the

The contributing editor for this article was T. Hirato.

Electronic supplementary material The online version of this article (https://doi.org/10.1007/s40831-018-0169-1) contains supplementary material, which is available to authorized users.

Kerstin Forsberg

kerstino@kth.se

1 Department of Chemical Engineering, KTH Royal Institute of Technology, Teknikringen 42, 10044 Stockholm, Sweden landfill and follow the European legislations for handling waste [2], recycling of NiMH batteries is an inevitable requirement for both economic and environmental reasons.

There are many studies on how to recycle batteries, from small-sized household batteries to the large-sized batteries used in vehicles [3-8]. Several techniques have been applied for the recovery of REEs and other valuable elements from NiMH batteries including acid leaching with various acids [3, 4, 7, 9-16], precipitation and solvent extraction methods with various reagents [5, 17-22], and pyrometallurgical methods [6, 23-25].

The objective of this study is to investigate a method that first transforms all the constituent elements of active material in a NiMH battery into their sulfate form by mixing with sulfuric acid and then roasting the dried mixture at a specific temperature for a certain amount of time. The resultant solid is a mixture of REE sulfates and the other elements in their oxide forms. Leaching the solid phase with water at ambient temperature will allow for the dissolution of rare earth sulfates and leave the rest of the elements in the leach residue as oxides. In the proposed method, the REEs are separated from the other elements present and the key process parameters are easy to control. Similar methods have been proposed to process nickel sulfide concentrates in a two-step process of oxidation- 
sulfation $[26,27]$ and to process limonitic nickel laterites with a sulfation-roasting-leaching process [28]. Selective sulfation with $\mathrm{SO}_{2}$ followed by water leaching has also been proposed for extraction of manganese from manganese oxide ore with high iron content [29]. Recent efforts have also been made to recover REEs from bauxite residue and from $\mathrm{NdFeB}$ magnets by sulfation, selective roasting, and water leaching $[30,31]$. The key outcome in these processes is a total dissolution of the rare earth sulfates in water, while iron, nickel, cobalt, and other elements remain in their solid oxide form.

The Panasonic Prismatic Module 6.5 Ah nickel metal hydride (NiMH) $7.2 \mathrm{~V}$ plastic casing HEV battery (used in the present study) has been characterized [10, 32]. Solidphase characterization of the active electrode materials was done using powder X-ray diffraction (XRD) and scanning electron microscopy with energy dispersive spectroscopy (SEM-EDS), and the chemical compositions of the active materials were determined by inductively coupled plasma optical emission spectrometry (ICP-OES) analysis after total dissolution in a mixture of acids. The anode-active material consists of $\mathrm{Ce}_{0.47} \mathrm{La}_{0.34} \mathrm{Nd}_{0.14} \mathrm{Pr}_{0.05} \mathrm{Ni}_{3.56} \mathrm{Co}_{0.75}$ $\mathrm{Al}_{0.29} \mathrm{Mn}_{0.4}$ (01-076-7719), and $\mathrm{LaNi}_{5}$. The cathode-active material consists of nickel hydroxide with a substitution of cobalt, yttrium oxide, and metallic nickel and cobalt.

The main reactions during the sulfation process are presented below, where $\mathrm{M}$ represents any metal.

$$
\begin{aligned}
& \mathrm{aM}+\mathrm{bH}_{2} \mathrm{SO}_{4}(\mathrm{aq})=\mathrm{M}_{\mathrm{a}}\left(\mathrm{SO}_{4}\right)_{\mathrm{b}}(\mathrm{aq})+\mathrm{bH}_{2}(\mathrm{~g}) \\
& \mathrm{aM}+2 \mathrm{bH}_{2} \mathrm{SO}_{4}(\mathrm{aq})= \mathrm{M}_{\mathrm{a}}\left(\mathrm{SO}_{4}\right)_{\mathrm{b}}(\mathrm{aq})+2 \mathrm{bH}_{2} \mathrm{O}(\mathrm{g}) \\
&+\mathrm{bSO}_{2}(\mathrm{~g})
\end{aligned}
$$

All through the treatment, $\mathrm{SO}_{2}$ gas evolution is expected due to the strong oxidizing properties of the concentrated sulfuric acid. The kinetics is controlled by the temperature and possibly by the formation of sulfate or oxide layers on the surface of the metal particles and their resistance to dissolve in the acidic and high-temperature surroundings created by the exothermic reaction.

The thermal stability of the metal sulfates during the decomposition is a critical step to be considered in the selective roasting. Thermal decompositions of the $\mathrm{Ni}, \mathrm{Co}$, and REE sulfates have been studied extensively [31, 33-38]. Solubility data of different REE, Ni, and Co sulfate hydrates and stability constants for the formation of different REE, $\mathrm{Ni}$, and Co sulfate complexes are available in the literature [39-41]. An important aspect is the formation of intermediate products during the selective roasting, such as rare earth oxysulfates. The solubilities of REE oxysulfates are limited in water; however, they dissolve under more acidic conditions. Most metals in oxide forms are almost insoluble in water. This shows the importance of the roasting temperature in order to obtain a high yield for the recovery of REEs in the aqueous phase and $\mathrm{Ni}$ and $\mathrm{Co}$ in the solid phase in their oxide forms after water leaching [42-44].

\section{Experimental Procedure}

The battery was manually disassembled, and the anodeand cathode-active materials were grinded separately. The active materials were mixed with concentrated sulfuric acid at room temperature to facilitate the sulfation process. The mixture was then dried and afterward roasted in a ventilated furnace at a fixed temperature for a certain amount of time. The roasted solid mixture was collected and leached with water at ambient temperature. During the selective water-leaching step, liquid samples were collected for analysis with ICP-OES, and at the end of the leaching, the solid residue was separated for powder XRD and SEMEDS analyses. The complete set of experiments is presented in Table 1.

\section{Material Characterization}

The elemental compositions of the cathode and anode materials were determined by performing a total dissolution of dry samples of the respective materials using a strong acid cocktail of perchloric acid, hydrochloric acid, and nitric acid at $85^{\circ} \mathrm{C}$. The solution was then allowed to reach room temperature before dilution and elemental analysis by ICP-OES.

Differential scanning calorimetry (DSC) and thermogravimetric analysis (TGA) at a heating rate of $10{ }^{\circ} \mathrm{C} / \mathrm{min}$ under $\mathrm{O}_{2}$ atmosphere and $100 \mathrm{~mL} / \mathrm{min}$ dry air flow were used to investigate the thermal decomposition behaviors of the materials (Mettler-Toledo, model-TGA/DSC 1). The samples used in the DSC/TGA analyses were prepared by mixing an equal weight mixture of anode- and cathodeactive materials with $12 \mathrm{~mol} / \mathrm{L}$ of sulfuric acid with solidto-liquid $(\mathrm{s} / \mathrm{L})$ ratio of $1 / 5$. The sample was then dried at $150{ }^{\circ} \mathrm{C}$ for $24 \mathrm{~h}$ and thereafter grinded into powder form.

For the characterization of the roasted materials before and after water leaching, scanning electron microscope was used with EDS capabilities (Hitachi S-3700N) as well as powder XRD (CuK $\alpha$ radiation, Siemens, Model D5000) for phase analyses.

\section{Sulfation and Selective Roasting}

The anode-active material was first grinded and sieved to obtain a powder with particle sizes $<38 \mu \mathrm{m}$. In the majority of the experiments, anode material was used since the REEs are concentrated in the anode-active material. 
Table 1 Experimental conditions for the sulfation and roasting steps

\begin{tabular}{|c|c|c|c|c|c|}
\hline Experiments & $\begin{array}{l}\mathrm{H}_{2} \mathrm{SO}_{4} \text { conc. for sulfation (mol/ } \\
\mathrm{L})\end{array}$ & $\begin{array}{l}\mathrm{s} / \mathrm{L} \text { of sulfation } \\
\text { step }\end{array}$ & $\begin{array}{l}\text { Roasting temp } \\
\left({ }^{\circ} \mathrm{C}\right)\end{array}$ & $\begin{array}{l}\text { Duration of roasting } \\
\text { (h) }\end{array}$ & Active materials used \\
\hline R1 & 12 & $1 / 5$ & 850 & 1 & Anode \\
\hline $\mathrm{R} 2$ & 12 & $1 / 5$ & 850 & 2 & Anode \\
\hline R3 & 12 & $1 / 5$ & 850 & 3 & Anode \\
\hline R4 & 12 & $1 / 5$ & 800 & 2 & Anode \\
\hline R5 & 10 & $1 / 5$ & 850 & 2 & Anode \\
\hline R6 & 8 & $1 / 5$ & 850 & 2 & Anode \\
\hline $\mathrm{R} 7$ & 6 & $1 / 5$ & 850 & 2 & Anode \\
\hline $\mathrm{R} 8$ & 4 & $1 / 5$ & 850 & 2 & Anode \\
\hline R9 & 2 & $1 / 5$ & 850 & 2 & Anode \\
\hline $\mathrm{R} 10$ & 8 & $1 / 5$ & 850 & 2 & $\begin{array}{l}\text { Anode and cathode } \\
\text { mixture }\end{array}$ \\
\hline $\mathrm{R} 11$ & 12 & $1 / 5$ & 900 & 2 & Anode \\
\hline $\mathrm{R} 12$ & 14 & $1 / 5$ & 850 & 2 & Anode \\
\hline $\mathrm{R} 13$ & 3.5 & $1 / 5$ & 850 & 2 & Anode \\
\hline $\mathrm{R} 14$ & 1.75 & $1 / 10$ & 850 & 2 & Anode \\
\hline R15 & 0.875 & $1 / 20$ & 850 & 2 & Anode \\
\hline
\end{tabular}

Based on the performance of the separation of REE from the anodic material, the same conditions should be applicable to the cathode material and/or their mixture. The conditions for the roasting experiments are presented in Table 1. Acidic solutions were prepared by adding analytical grade sulfuric acid to deionized water. The solid-toliquid ratios 1/5, 1/10 and 1/20 were studied to compare the effect of amount of acid versus acid concentration. Weighed samples of the dry solid material $(1 \mathrm{~g})$ were mixed with the aqueous phases in individual alumina crucibles using a silica fume glass rod. During this step gas evolution was observed. Constant stirring with the silica fume glass rod was important in order to avoid losing material due to bubbling of the gas evolved. The bubbling should be prevented as much as possible otherwise active battery material could escape from the crucible carried on the surface of the bubbles since the particle size is fine. Stirring also helped to avoid possible sintering of the material due to the heat evolved from the reaction. With the help of the silica fume glass rod, the bottom of the crucible was constantly swiped to force the reaction of all solid material with the acid.

A sharp decrease in intensity of the bubbling was observed with the decreasing acid concentration in experiments R4-R9. After the gas evolution stopped, the samples were dried in a furnace with ventilation. The drying was conducted at $150{ }^{\circ} \mathrm{C}$ for $24-72 \mathrm{~h}$, until no difference in the sample weight over time was detected. The importance of the drying process before the roasting is to give the slurry enough time to complete the metal-acid reactions as well as to prevent instant boiling and loss of material due to splashing and liquid gas movement just after placing the crucible in the preheated furnace. Mixtures with lower initial acid concentrations $(2 \mathrm{M}, 4 \mathrm{M}, 6 \mathrm{M}$, and $8 \mathrm{M})$ were sufficiently dried at $150{ }^{\circ} \mathrm{C}$ for $24 \mathrm{~h}$. The slurries prepared with high acid concentrations (10M, 12M, and 14M) required 48 to $72 \mathrm{~h}$ of drying.

The dried samples were then roasted in an electrical furnace at 800,850 , or $900{ }^{\circ} \mathrm{C}$. The residence time was varied from 1 to $3 \mathrm{~h}$. This roasting process allowed the $\mathrm{Ni}$ and Co sulfate solid phases to decompose into their oxide forms while the REE remained in their sulfate forms. The temperature was selected based on available literature data on the thermal decomposition temperature range of the sulfates of REEs, nickel and cobalt [31, 33-38, 45].

\section{Water Leaching}

The roasted material obtained from the selective roasting stage was carefully scraped off from the crucible and put in polyethylene (PE) bottles for water leaching using deionized water $(50 \mathrm{~mL}$ for $1 \mathrm{~g}$ of solid material). Part of the water was used to wash the crucibles before being transferred into HDPE bottles for leaching. The weight of the crucibles was noted before roasting and after water washing to know whether there was a material loss or not. The bottles were placed in a water bath held at $25{ }^{\circ} \mathrm{C} \pm 0.1{ }^{\circ} \mathrm{C}$. Each sample was continuously stirred (500 rpm) using magnetic bars. Samples of the aqueous phase were taken after 1,24 and $72 \mathrm{~h}$ by using a syringe and solid material 
was immediately separated from the aqueous phase by using a syringe filter $(0.2 \mu \mathrm{m})$. The leach residues were separated from the leach liquor after $72 \mathrm{~h}$ of leaching by using filter paper $(0.2 \mu \mathrm{m})$. All aqueous phases were stored in HDPE bottles prior to ICP-OES analysis. Solid phases were analyzed with SEM-EDX and powder XRD. The $\mathrm{pH}$ after water leaching under optimal conditions was measured by using an Orion ROSS electrode, which was calibrated by Thermo Fisher Scientific standard solutions at $\mathrm{pH}$ 2,4 , and 7 . The recovery percentages of the elements were calculated based on the measured aqueous concentrations of the elements after water leaching in relation to the total composition of the original materials.

\section{Results and Discussion}

\section{Material Characterization}

The weight percentages of the elements in the anode- and cathode-active material are presented in Table 2. The leach residue was $3.5 \%$ of the initial weight. An attempt to dissolve the residue in a fresh portion of acid mixture was not successful.

The data from the TGA is presented in Fig. 1. The first major weight loss starts at $25{ }^{\circ} \mathrm{C}$ and continues until $119^{\circ} \mathrm{C}$; this weight loss is due to a physical dehydration of the material. As seen in Fig. 1, the physically and chemically bonded water removal is completed around $286{ }^{\circ} \mathrm{C}$, which agrees with previous work for materials of similar composition [31, 46, 47]. Initial decomposition temperatures measured by TGA normally vary depending on the characteristics of the solids (particle size, shape, quantity), the sample holder, the heating rate and the composition of the gas phase [35]. Lanthanum and cerium makes up the major part of the REE fraction of the sample (see Table 2). According to literature data decomposition of cerium sulfate hydrate occurs from about $75{ }^{\circ} \mathrm{C}$ with complete dehydration at about $300{ }^{\circ} \mathrm{C}$ and the dehydration of lanthanum sulfate hydrate is observed between 175 and $300{ }^{\circ} \mathrm{C}[35,47,48]$. The existence of endothermic peaks at 78, 105 and $209^{\circ} \mathrm{C}$ (see Fig. 1) also indicates dehydration since all these reactions are endothermic. The endothermic peak located at $586{ }^{\circ} \mathrm{C}$ results from the decomposition of the nickel, cobalt and other minor element sulfates. The decompositions have been reported to occur at temperatures of 810 and $916{ }^{\circ} \mathrm{C}$ for nickel sulfate and cobalt sulfate, respectively $[35,37,48,49]$. The thermal decomposition of nickel sulfate into nickel oxide is designated by the massive weight loss located in the center of the graph by considering the high mass percentage of nickel with respect to the rest of the elements. At temperatures greater than about $900{ }^{\circ} \mathrm{C}$, rare earth sulfates are expected to decompose into rare earth oxysulfates, which are practically insoluble in water [42]. Lanthanum oxysulfate was identified in the XRD pattern of the solid residues after water leaching in the roasting experiment $\mathrm{R} 11$, performed at $900{ }^{\circ} \mathrm{C}$, Fig. $5 \mathrm{~b}$. Based on these results, a temperature interval from 800 to $850{ }^{\circ} \mathrm{C}$ was selected for the selective roasting in order to obtain a maximum yield of REE(III) in the water-leaching step.

\section{Sulfation and Selective Roasting}

The EDS result of mapping analysis of a particle in experiment R6 after sulfation but before roasting is given in Table 3. The atomic ratio of the sulfur and oxygen indicates that the elements are mainly present as sulfates after the sulfation step.

The results from SEM-EDS mapping analyses of the solid phases obtained after roasting at $850{ }^{\circ} \mathrm{C}$ for $2 \mathrm{~h}$ (R6) are presented in Fig. 2. The results show the distribution of different elements within a selected region of the sample. The original image of the selected area is shown in the upper left corner with the scale of 20 micrometers. The rare earth sulfates have a glassy appearance compared to its surrounding. The mapping results show that the REEs are associated with $\mathrm{S}$ and $\mathrm{O}$ in the form of the sulfate ions and that $\mathrm{Ni}$ and $\mathrm{Co}$ are associated with $\mathrm{O}$ within the oxides. By investigating the small rare earth sulfate cluster in the upper right corner of the scanned area in Fig. 2, it can be seen that lanthanum is the dominating REE. This is in accordance with the overall composition of the anode material (see Table 2) where lanthanum is the REE present at the highest concentration. The same results were obtained by mapping analyses of other selected areas of the sample.
Table 2 Chemical composition of cathode and anode materials in mass percentage

\begin{tabular}{lllllllllllll}
\hline & $\mathrm{Ce}$ & $\mathrm{Co}$ & $\mathrm{La}$ & $\mathrm{Mn}$ & $\mathrm{Nd}$ & $\mathrm{Ni}$ & $\mathrm{Pr}$ & $\mathrm{Y}$ & $\mathrm{Al}$ & $\mathrm{Fe}$ & $\mathrm{Zn}$ & $\mathrm{K}$ \\
\hline $\begin{array}{l}\text { Cathode } \\
\text { (mass\%) }\end{array}$ & nd & 5.46 & $\mathrm{nd}$ & 0.11 & $\mathrm{nd}$ & 76.47 & $\mathrm{nd}$ & 0.43 & 0.09 & 0.14 & 3.70 & 0.62 \\
$\begin{array}{l}\text { Anode } \\
\text { (mass\%) }\end{array}$ & 6.22 & 4.96 & 19.88 & 4.33 & 2.63 & 54.18 & 2.40 & 0.71 & 2.02 & 0.09 & 1.45 & 0.44 \\
\hline
\end{tabular}

$N d$ not detected 
Fig. 1 DSC/TGA analysis of a mixture of anode and cathode material (color figure online)

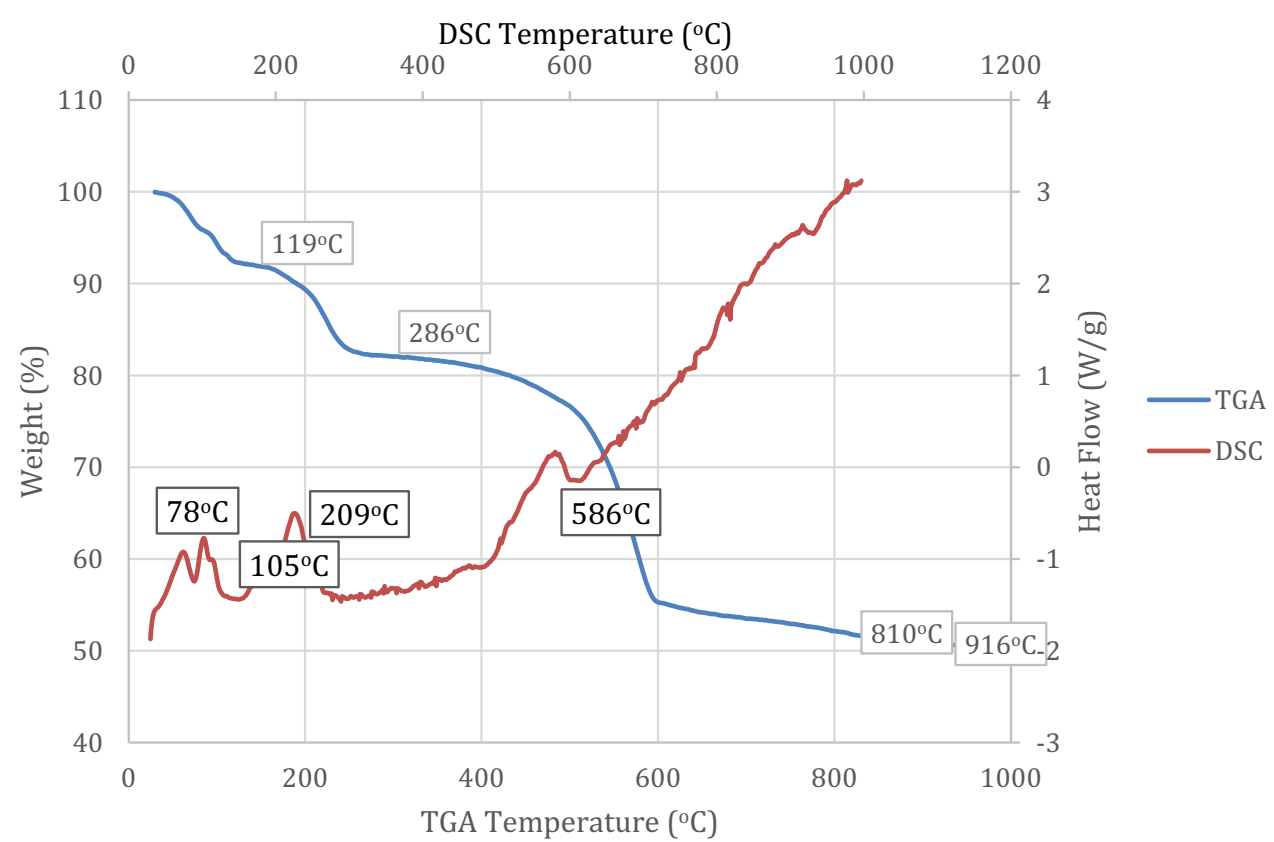

Table 3 EDS results of an area analysis after sulfation before roasting (exp. R6)

\begin{tabular}{lcc}
\hline Element & norm. wt $\%$ & atom. wt $\%$ \\
\hline $\mathrm{O}$ & 28.72 & 64.23 \\
$\mathrm{Al}$ & 1.62 & 2.21 \\
$\mathrm{~S}$ & 15.44 & 17.23 \\
$\mathrm{Co}$ & 0.59 & 0.36 \\
$\mathrm{Ni}$ & 6.01 & 3.66 \\
$\mathrm{Ce}$ & 12.21 & 3.12 \\
$\mathrm{Pr}$ & 2.25 & 0.57 \\
$\mathrm{Ne}$ & 4.57 & 1.12 \\
La & 27.73 & 7.15 \\
$\mathrm{Y}$ & 0.83 & 0.33 \\
Total & 100.00 & 100.00 \\
\hline
\end{tabular}

The atomic ratio of the sulfur and oxygen indicates that the elements are mainly present as sulfates

The powder XRD diffractogram of the solid phase obtained after roasting at $850{ }^{\circ} \mathrm{C}$ during $2 \mathrm{~h}$ (R6) is presented in Fig. 3a. Peaks belonging to nickel and cobalt oxides and to rare earth sulfates were identified.

After water leaching, the leach residue in the experiment R6 consisted of nickel and cobalt oxides together with traces of the other minor elements, as shown in Fig. $3 \mathrm{~b}$. Both the nickel and cobalt were in oxide form as well as the aluminum, zinc, and a small amount of iron. All the peaks belonging to the REE solid phases, which were present in the powder diffractogram before water leaching (Fig. 3), disappeared after leaching.

\section{Effect of Acid Concentration in the Sulfation Process}

The elemental recovery percentages after water leaching in experiments where the active material was roasted for $2 \mathrm{~h}$ at $850{ }^{\circ} \mathrm{C}$ are presented in Table 4 and Fig. 4 . The results reflect the influence of using different concentration of sulfuric acid in the sulfation step while keeping the solidto-liquid ratio constant. The recovery percentages of the rare earths $(\mathrm{La}, \mathrm{Ce}, \mathrm{Pr}, \mathrm{Nd}$, and $\mathrm{Y})$ are high as expected.

The stoichiometric need of sulfate ions for all elements to react and form sulfates can be obtained from a solution with $3.5 \mathrm{~mol} / \mathrm{L}$ sulfuric acid concentration with the given solid-to-liquid ratio (1/5). The main objective was to separate the REEs from the other elements present, and high recovery percentages of rare earths have been achieved even with low initial acid concentration of $2 \mathrm{~mol} / \mathrm{L}$ as readily seen in Table 2 . However, in order to reach the maximum recovery of REE after $1 \mathrm{~h}$ of water leaching, a sulfuric acid concentration of at least $8 \mathrm{~mol} / \mathrm{L}$ (exp. R6) is needed for a solid-to-liquid ratio of 1/5.

For the highest molarity of sulfuric acid $(14 \mathrm{~mol} / \mathrm{L}$, exp. R12), the recovery percentages of the REE are lower than those in the experiments where 8 or $10 \mathrm{~mol} / \mathrm{L}$ of sulfuric acid was used in the sulfation step; this is due to the formation of water-insoluble REE oxysulfates at high sulfuric acid concentration. Traces of REEs were found in the leach 


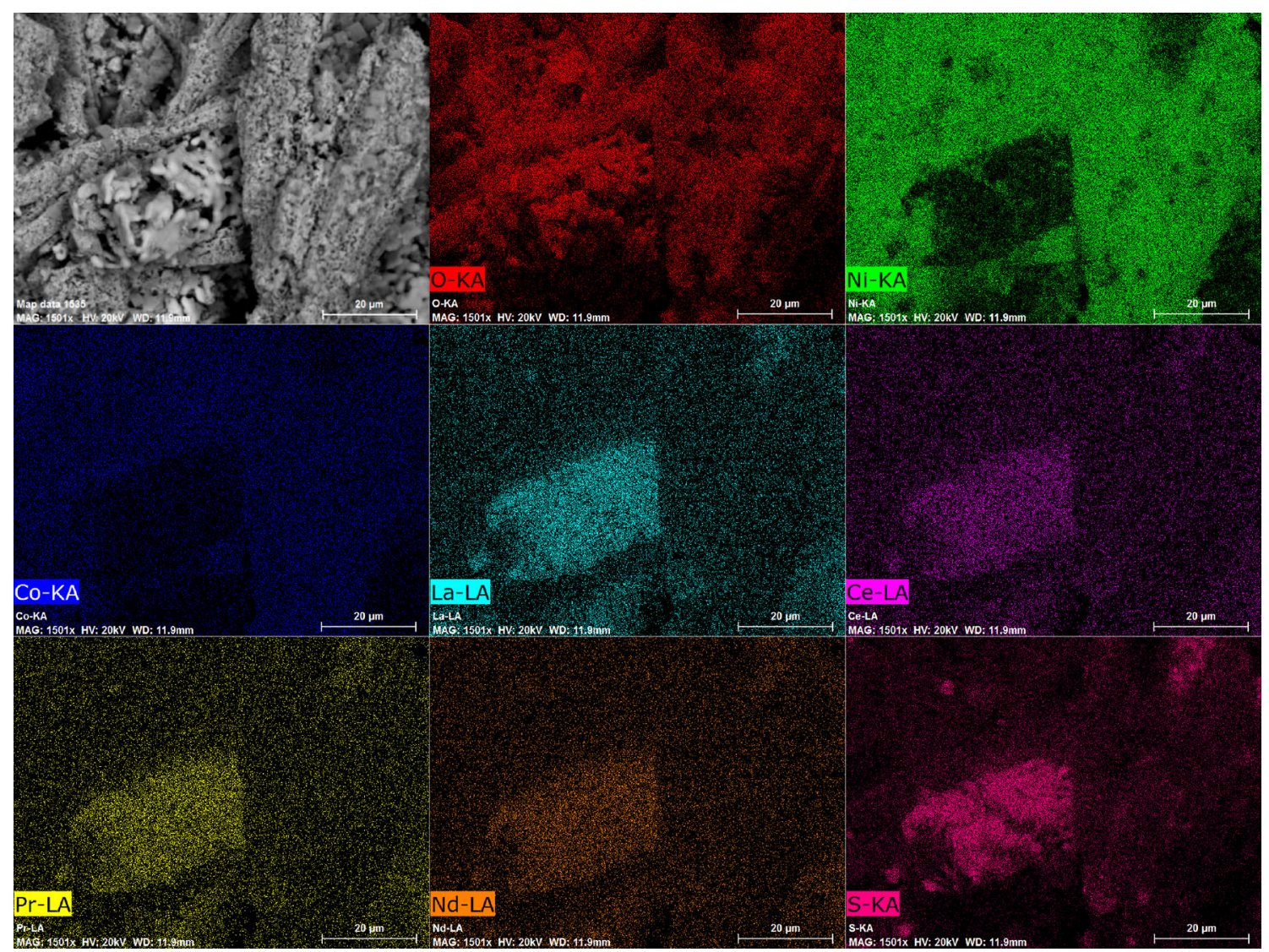

Fig. 2 Mapping analysis of the material after selective roasting at $850{ }^{\circ} \mathrm{C}$ during $2 \mathrm{~h}$ (R6). Scale marker $=20 \mu \mathrm{m}$ (Color figure online)

residue in experiment R12 (sulfation using $14 \mathrm{~mol} / \mathrm{L}$ of sulfuric acid) by SEM-EDS (see Table 5), which indicates the presence of insoluble REE oxysulfates. Traces of REE oxysulfates in the solid residue left after water leaching in experiment R12 were also identified by powder XRD analysis (see Fig. 5a). The recovery percentage of the heavy REE yttrium is lower than the recovery percentages of the light REE under all conditions studied. This can be explained by a higher tendency of yttrium to form oxysulfates compared to the lighter REE. Based on the results, a sulfuric acid concentration of $12 \mathrm{~mol} / \mathrm{L}$ or higher should be avoided to prevent the formation of undesired oxysulfate phases.

To further investigate the effect of the sulfuric acid concentration in the sulfation step, a series of experiments were conducted at different acid concentrations and by varying the solid-to-liquid ratio, while keeping the moles of sulfate ions constant (experiments R13-R15). As seen in Table 6, with the decreasing acid concentration, the elemental recovery of REE in the water leaching decreases. Thus, the concentration of acid in the investigated range and, not only the stoichiometric need of acid, is important in order to allow complete sulfation of all reactants.

\section{Effect of Roasting Duration}

The effect of the duration of roasting was studied by performing roasting experiments at $850{ }^{\circ} \mathrm{C}$ for 1,2 , and $3 \mathrm{~h}$ after sulfation using $12 \mathrm{~mol} / \mathrm{L}$ of sulfuric acid, as reported in Table 1. The dissolution percentages of nickel, cobalt, manganese, and aluminum after $1 \mathrm{~h}$ of roasting followed by water leaching at $25^{\circ} \mathrm{C}$ for 1,24 , and $72 \mathrm{~h}$ are presented in Fig. 6a. The results show that nickel, cobalt, manganese, and aluminum dissolve in the aqueous phase during the water leaching. After $72 \mathrm{~h}$, the dissolution of nickel was $62.8 \%$. This means that $1 \mathrm{~h}$ of roasting at $850{ }^{\circ} \mathrm{C}$ is not enough to completely turn the nickel and cobalt sulfates into their insoluble oxide forms. In the experiments where the samples were roasted for 2 and $3 \mathrm{~h}$ (R2 and R3), the dissolutions of $\mathrm{Ni}$ and $\mathrm{Co}$ were much lower $(0.08 \% \mathrm{Ni}$ and $0.65 \% \mathrm{Co}$ and $0.05 \% \mathrm{Ni}$ and $0.39 \% \mathrm{Co}$ after 2 and $3 \mathrm{~h}$ of water leaching, respectively), which shows that $2 \mathrm{~h}$ is enough to complete the transformation of $\mathrm{Ni}$ and $\mathrm{Co}$ into oxides.

The leaching percentage recoveries of the light REE La, $\mathrm{Ce}, \mathrm{Pr}, \mathrm{Nd}$, and $\mathrm{Y}$ are presented in Fig. 6b. The recovery of $\mathrm{La}$ is $>93 \%$ already after $1 \mathrm{~h}$ of water leaching for 1 and $2 \mathrm{~h}$ of roasting. However, it can be seen that the recoveries 

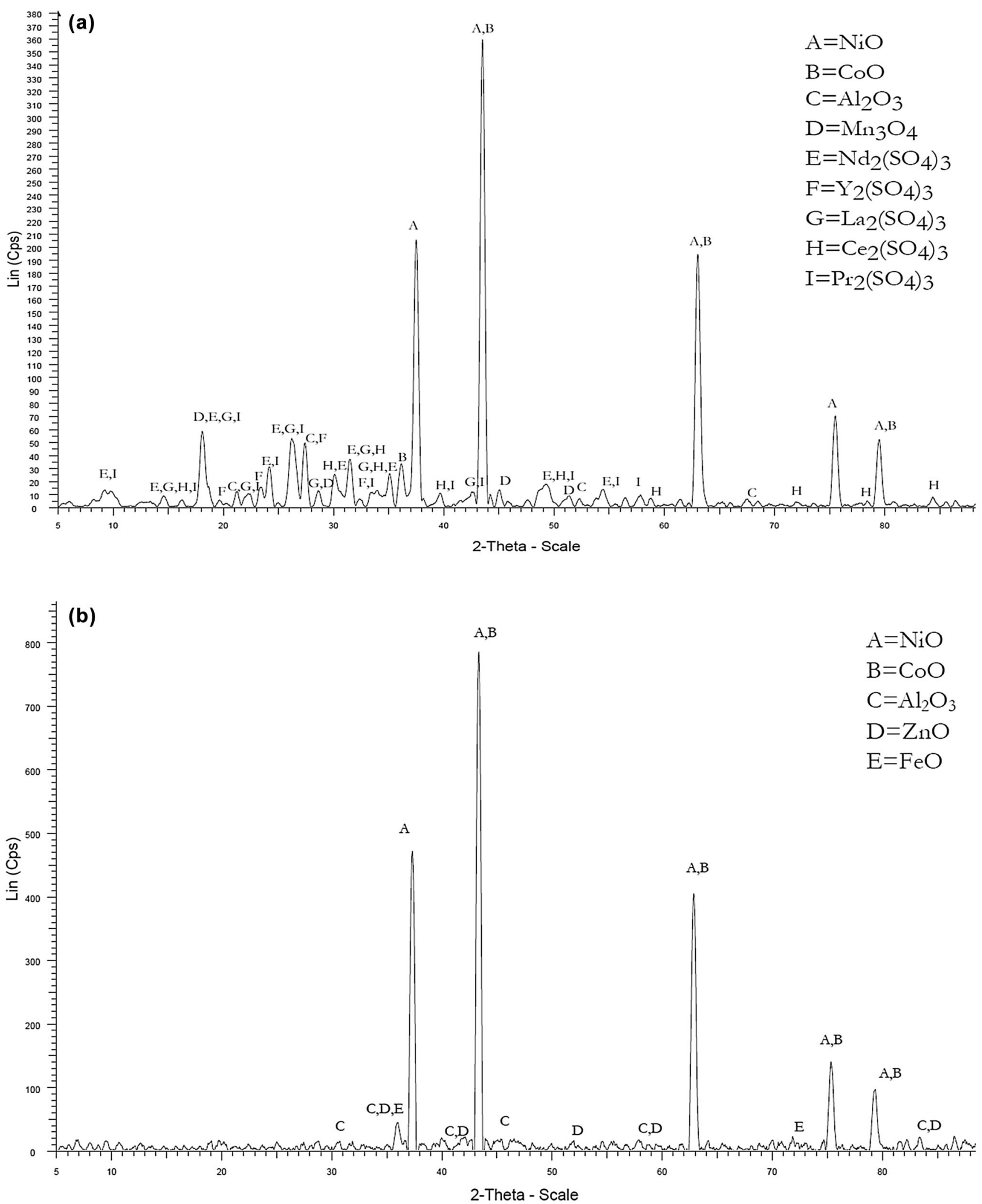

Fig. 3 a XRD patterns of the solid phase after sulfation using $8 \mathrm{~mol} / \mathrm{L}$ of $\mathrm{H} 2 \mathrm{SO} 4$ and selective roasting at $850{ }^{\circ} \mathrm{C}$ (R6), b XRD patterns of the solid phase after selective water leaching (R6) (color figure online) 
Table 4 Percentage recoveries of elements after $1 \mathrm{~h}$ of water leaching at $25^{\circ} \mathrm{C}$
Fig. 4 Percentage recovery of REE after $1 \mathrm{~h}$ of water leaching versus acid concentration in the sulfation step (exp. R2, R5, R6, R7, R8, R9). All samples have been roasted for $2 \mathrm{~h}$ at $850{ }^{\circ} \mathrm{C}$ (color figure online)

\begin{tabular}{|c|c|c|c|c|c|c|c|c|c|c|c|}
\hline \multirow[t]{2}{*}{ Exp. } & \multirow[t]{2}{*}{ Conc. $\mathrm{H}_{2} \mathrm{SO}_{4}(\mathrm{~mol} / \mathrm{L})$} & \multicolumn{10}{|c|}{ Elemental recovery\% } \\
\hline & & $\mathrm{La}$ & $\mathrm{Ce}$ & $\operatorname{Pr}$ & $\mathrm{Nd}$ & $\mathrm{Y}$ & $\mathrm{Ni}$ & Co & $\mathrm{Al}$ & $\mathrm{Mn}$ & $\mathrm{Fe}$ \\
\hline R9 & 2 & 90.5 & 77.1 & 85.4 & 83.2 & 56.0 & nd & 0.4 & 1.3 & 0.8 & 0.2 \\
\hline R8 & 4 & 93.4 & 83.7 & 91.8 & 89.9 & 71.2 & nd & 0.5 & 1.4 & 1.4 & 0.5 \\
\hline R7 & 6 & 91.4 & 83.2 & 90.2 & 87.9 & 73.0 & nd & 0.5 & 1.4 & 1.5 & 0.3 \\
\hline R6 & 8 & 93.8 & 93.3 & 93.5 & 93.8 & 89.1 & nd & 1.1 & 1.5 & 3.5 & nd \\
\hline R5 & 10 & 92.3 & 95.5 & 93.6 & 93.1 & 92.3 & nd & 1.8 & 1.5 & 8.8 & nd \\
\hline R2 & 12 & 93.8 & 88.4 & 96.6 & 91.4 & 74.3 & nd & 0.6 & 1.7 & 2.1 & nd \\
\hline R12 & 14 & 84.0 & 62.2 & 70.0 & 82.0 & 74.6 & nd & nd & 0.7 & 1.4 & nd \\
\hline
\end{tabular}

All samples have been roasted for $2 \mathrm{~h}$ at $850{ }^{\circ} \mathrm{C}$ in contact with sulfuric acid of different molarity keeping the solid-to-liquid ratio of $1 / 5$

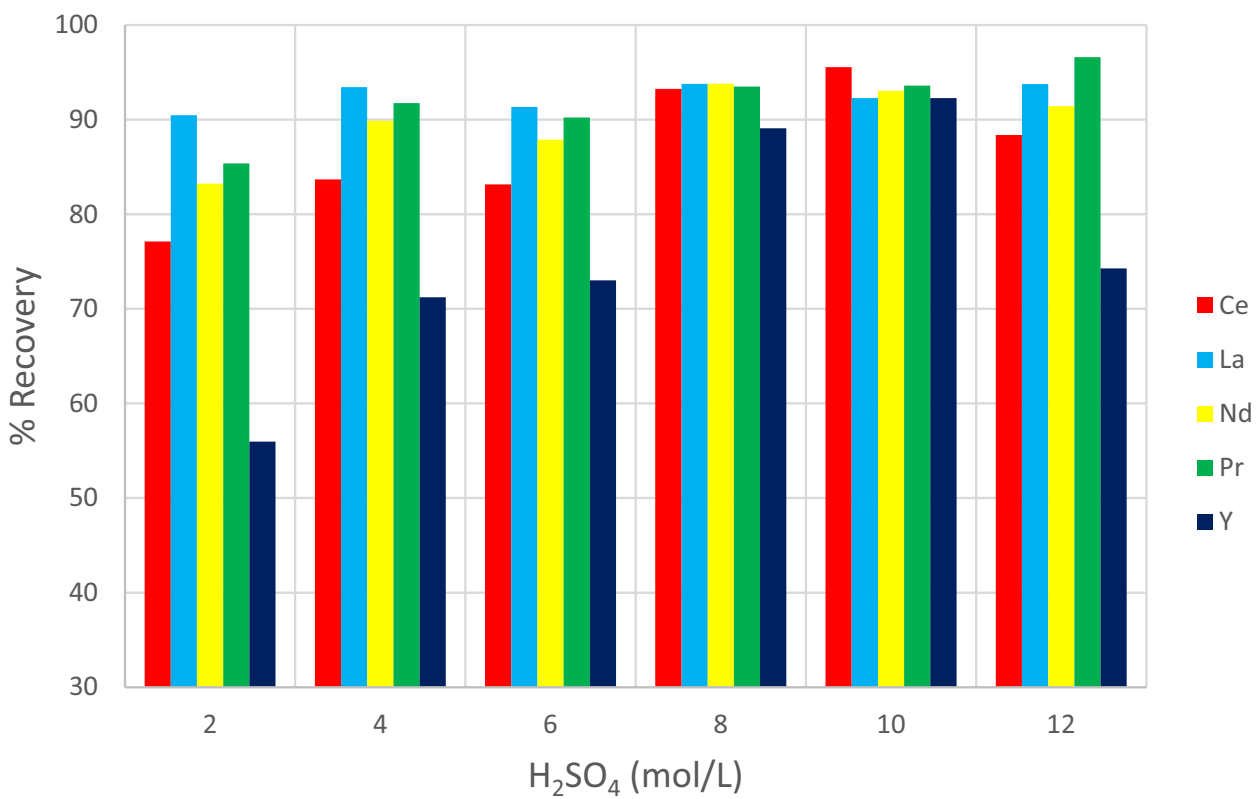

Table 5 EDS results of a point analyses of leach residue after water leaching (exp. R12)

\begin{tabular}{lcc}
\hline Element & norm. wt\% & atom. wt $\%$ \\
\hline $\mathrm{O}$ & 23.76 & 53.22 \\
$\mathrm{Al}$ & 0.38 & 0.50 \\
$\mathrm{Mn}$ & 2.04 & 1.33 \\
$\mathrm{Co}$ & 4.92 & 2.99 \\
$\mathrm{Ni}$ & 67.01 & 40.92 \\
$\mathrm{~S}$ & 0.64 & 0.71 \\
La & 1.25 & 0.32 \\
Total & 100.00 & 100.00 \\
\hline
\end{tabular}

of the REE, most notably of $\mathrm{Y}$, decrease as the time of roasting increases. A possible explanation for this observation can be that part of the REE, given enough time, turns into water-insoluble REE oxysulfates also at $850{ }^{\circ} \mathrm{C}$. The optimal roasting time is thus $2 \mathrm{~h}$, which is sufficient to turn the $\mathrm{Ni}$ and Co sulfates into oxides, while it is short enough to prevent the REE sulfates to turn into waterinsoluble oxysulfates.

\section{Effect of Roasting Temperature}

Figure 7 shows the recovery percentages after 1, 24, and $72 \mathrm{~h}$ of water leaching in experiments R2 and R4 using a roasting temperature of 800 and $850{ }^{\circ} \mathrm{C}$, respectively (see Table 1). The results show that nickel, cobalt, and manganese dissolve to a higher degree in the water-leaching step after roasting at $800{ }^{\circ} \mathrm{C}$ than when roasting at $850{ }^{\circ} \mathrm{C}$. The results indicate that the nickel and cobalt sulfates did not fully transform into water-insoluble oxides during the roasting step at $800{ }^{\circ} \mathrm{C}$. After $72 \mathrm{~h}$ of leaching time, the recovery percentages of yttrium are $98 \%$ after roasting at 

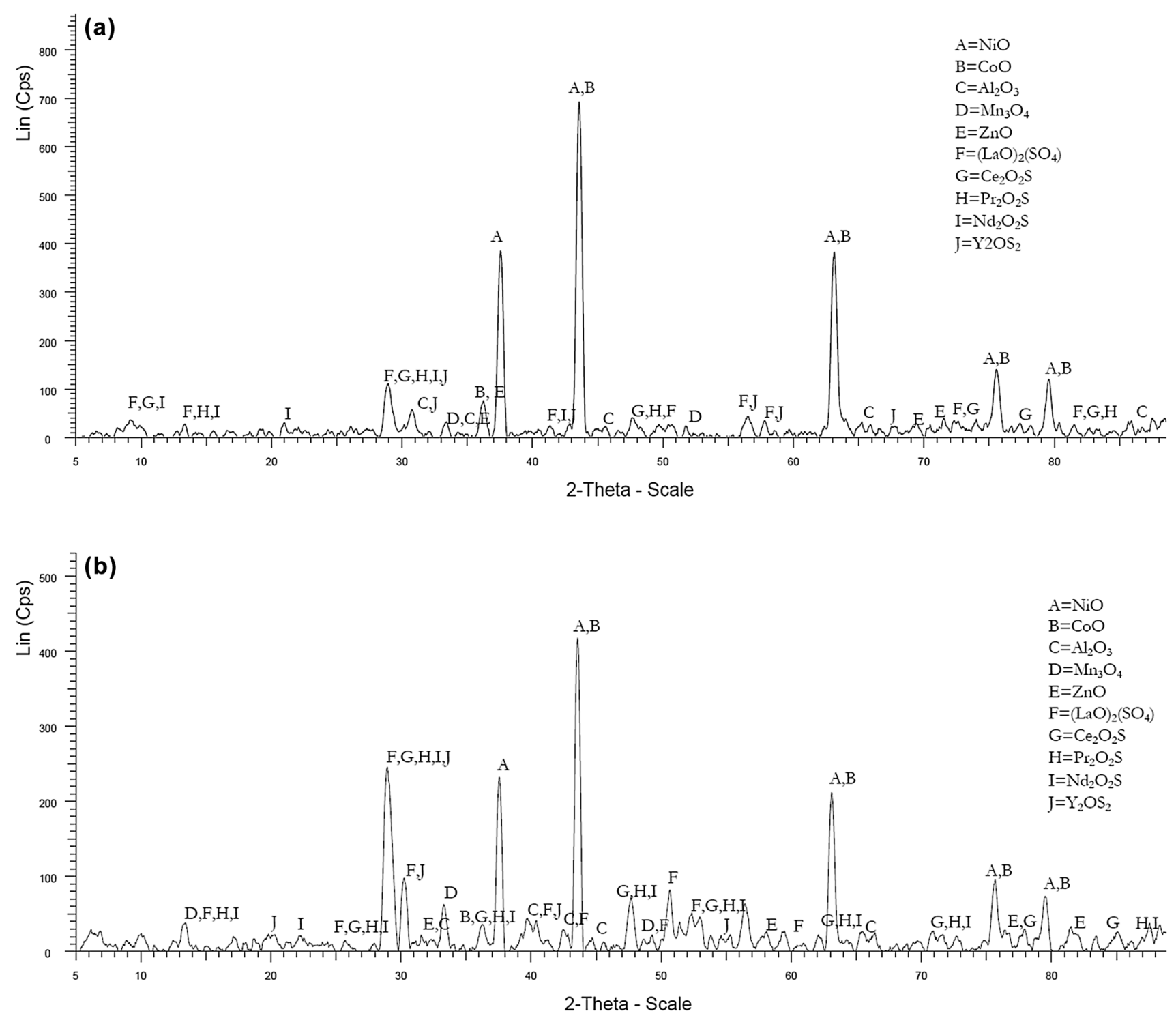

Fig. 5 a XRD patterns of the leach residue after water leaching in

experiment $\mathrm{R} 11$ with sulfation using $12 \mathrm{~mol} / \mathrm{L}$ of $\mathrm{H}_{2} \mathrm{SO}_{4}$ and roasting experiment $\mathrm{R} 12$ with sulfation using $14 \mathrm{~mol} / \mathrm{L}$ of $\mathrm{H}_{2} \mathrm{SO}_{4}$ and roasting at $850{ }^{\circ} \mathrm{C}$; $\mathbf{b}$ XRD patterns of the leach residue after water leaching in at $900{ }^{\circ} \mathrm{C}$ (color figure online)

Table 6 Percentage recoveries of elements after $1 \mathrm{~h}$ of water leaching at $25^{\circ} \mathrm{C}$

\begin{tabular}{|c|c|c|c|c|c|c|c|c|c|c|c|c|}
\hline \multirow[t]{2}{*}{ Exp. } & \multirow[t]{2}{*}{$\mathrm{s} / \mathrm{L}$} & \multirow[t]{2}{*}{ Conc. $\mathrm{H}_{2} \mathrm{SO}_{4}(\mathrm{~mol} / \mathrm{L})$} & \multicolumn{10}{|c|}{ Elemental recovery $\%$} \\
\hline & & & $\mathrm{La}$ & $\mathrm{Ce}$ & $\operatorname{Pr}$ & $\mathrm{Nd}$ & $\mathrm{Y}$ & $\mathrm{Ni}$ & Co & $\mathrm{Al}$ & Mn & $\mathrm{Fe}$ \\
\hline R13 & $1 / 5$ & 3.5 & 93.7 & 89.2 & 88.2 & 96.7 & 87.7 & nd & nd & 1.5 & 4.7 & 2.8 \\
\hline R14 & $1 / 10$ & 1.75 & 90.9 & 81.7 & 79.6 & 93.8 & 78.2 & nd & nd & 1.2 & 1.3 & 4.4 \\
\hline R15 & $1 / 20$ & 0.875 & 91.5 & 76.3 & 74.5 & 91.8 & 64.8 & nd & nd & 1.2 & 0.3 & nd \\
\hline
\end{tabular}

All samples have been roasted for $2 \mathrm{~h}$ at $850{ }^{\circ} \mathrm{C}$
$800{ }^{\circ} \mathrm{C}(\mathrm{R} 4)$ and $81 \%$ after roasting at $850{ }^{\circ} \mathrm{C}(\mathrm{R} 2)$. These experiments were performed using $12 \mathrm{~mol} / \mathrm{L}$ of sulfuric acid in the sulfation step. The lower recovery of yttrium after roasting at $850{ }^{\circ} \mathrm{C}$ could be due to the formation of yttrium oxysulfate, which is favored for higher concentration of sulfuric acid in the sulfation step and at higher 
Fig. 6 a Percentages of dissolution of $\mathrm{Ni}, \mathrm{Co}, \mathrm{Mn}$, and $\mathrm{Al}$ after 1, 24, and $72 \mathrm{~h}$ of water leaching in experiments where the roasting duration was $1 \mathrm{~h}$ (R1). In all experiments, the sulfation was performed using $12 \mathrm{~mol} / \mathrm{L}$ sulfuric acid, and the roasting temperature was $850{ }^{\circ} \mathrm{C} ; \mathbf{b}$ percentage recoveries of REE after 1-hour water leaching in experiments where the roasting durations were $1 \mathrm{~h}$ (R1), $2 \mathrm{~h}$ (R2), and $3 \mathrm{~h}$ (R3). In all the experiments, the sulfation was performed using $12 \mathrm{~mol} / \mathrm{L}$ sulfuric acid, and the roasting temperature was $850{ }^{\circ} \mathrm{C}$ (color figure online)
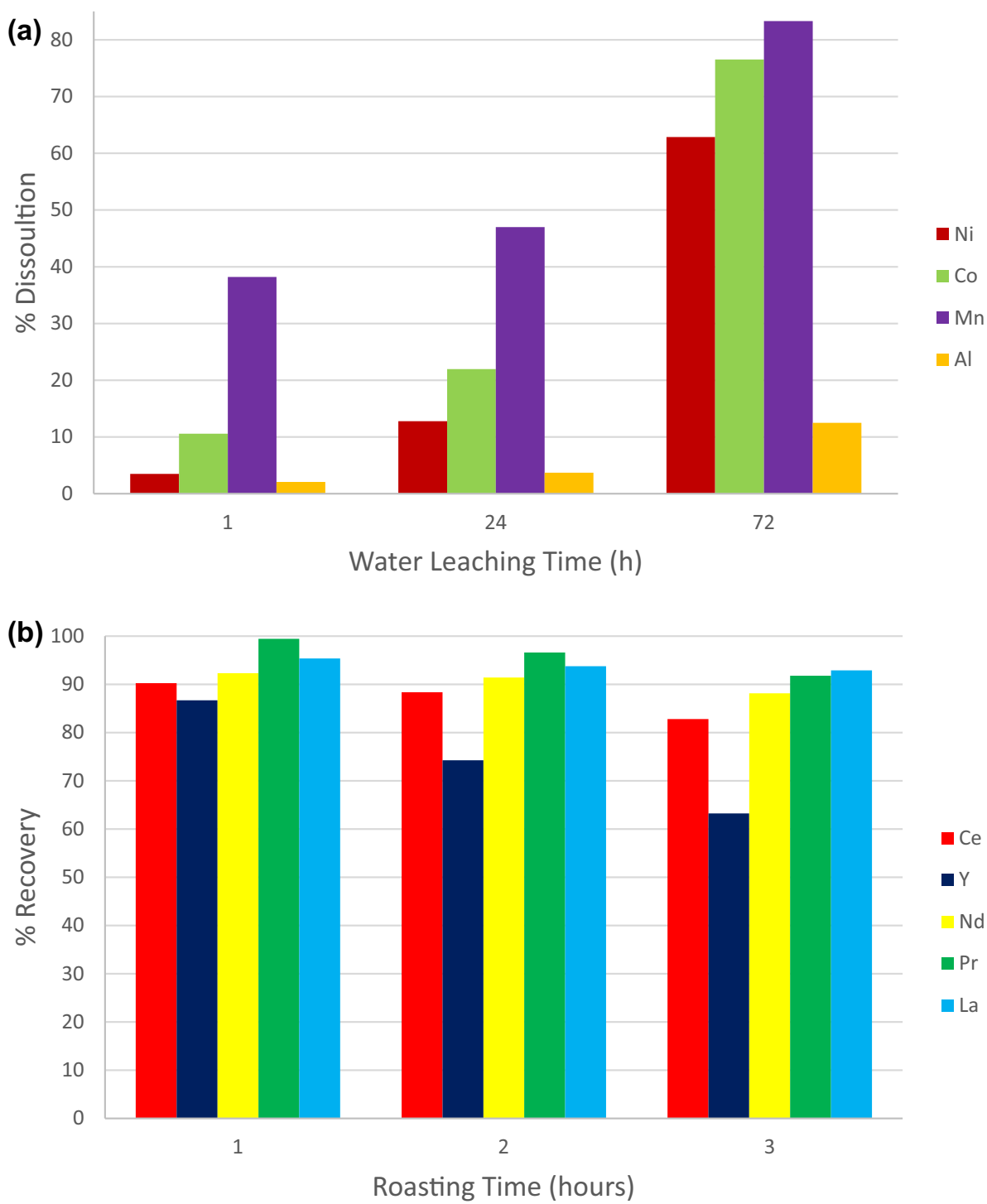

roasting temperatures. The time to completely dissolve yttrium is shorter in experiment $\mathrm{R} 2\left(850{ }^{\circ} \mathrm{C}\right.$ roasting $)$ than that in the experiment $\mathrm{R} 4\left(800{ }^{\circ} \mathrm{C}\right.$ roasting); this can be attributed to yttrium forming mixed $\mathrm{Co}$ and $\mathrm{Ni}$ sulfates making the time to completely dissolve $\mathrm{Y}$ longer than for the case when $\mathrm{Ni}$ and $\mathrm{Co}$ are completely transformed into oxides. The leaching recoveries for the light REE, represented by La, after $1 \mathrm{~h}$ of water leaching were $>92 \%$ and $>94 \%$ after roasting for $2 \mathrm{~h}$ at 800 and $850{ }^{\circ} \mathrm{C}$, respectively ( $\mathrm{R} 2$ and $\mathrm{R} 4)$. The water-leaching recovery of REE in experiment R11, where the roasting was performed at $900{ }^{\circ} \mathrm{C}$, was less than $5 \%$. The solid residue after water leaching in experiment R11 was investigated by powder $\mathrm{XRD}$, and the diffractogram indicated the formation of oxysulfates, as seen in Fig. 5b, which would explain the low REE recovery percentages in the water-leaching step. In addition, a pure sample of yttrium sulfate hydrate crystals was synthesised and analyzed separately by TGA/ DSC (see, Supplementary Figure S1), indicating the formation of yttrium oxysulfates above about $900{ }^{\circ} \mathrm{C}$.

\section{Water Leaching}

The results from water-leaching step are presented in Figs. 4, 6a, b, and 7. The results show that $1 \mathrm{~h}$ of water leaching is sufficient to dissolve nearly all of the REE sulfates with only a small increase in the total recovery percentage after $72 \mathrm{~h}$. In those cases, where the samples contain $\mathrm{Ni}$ and $\mathrm{Co}$ sulfates after the roasting step, the concentrations of $\mathrm{Ni}$ and $\mathrm{Co}$ in the aqueous phase increase substantially between 24 and $72 \mathrm{~h}$ of water leaching, as seen in Figs. 6a and 7. No precipitation was observed in any of the leaching experiments. 
Fig. 7 Percentage recoveries of $\mathrm{Ni}, \mathrm{Co}$, and $\mathrm{Mn}$ after different durations of water leaching at $25{ }^{\circ} \mathrm{C}$. The samples have been roasted for $2 \mathrm{~h}$ at $800{ }^{\circ} \mathrm{C}$ (R4) or $850{ }^{\circ} \mathrm{C}(\mathrm{R} 2)$ after sulfation using $12 \mathrm{~mol} / \mathrm{L}$ of sulfuric acid (color figure online)

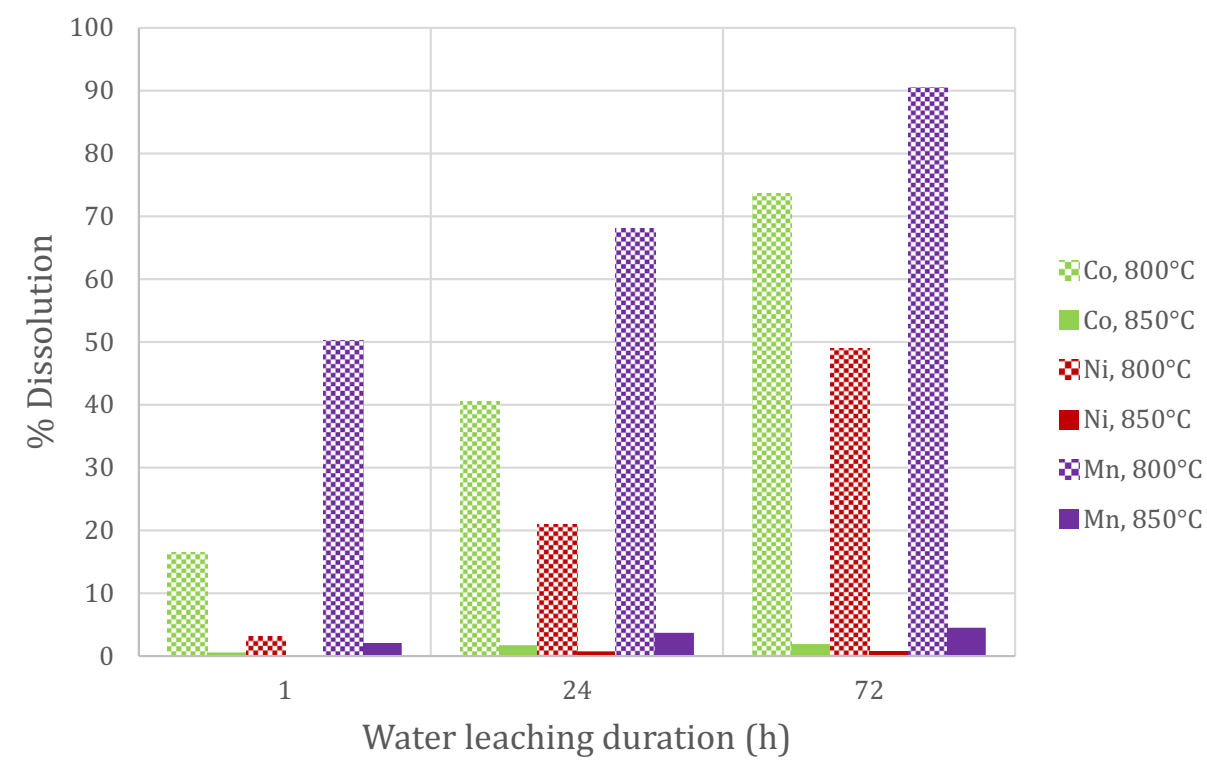

\begin{tabular}{lcccccccccc}
\hline & $\mathrm{La}$ & $\mathrm{Ce}$ & $\mathrm{Pr}$ & $\mathrm{Nd}$ & $\mathrm{Y}$ & $\mathrm{Ni}$ & $\mathrm{Co}$ & $\mathrm{Al}$ & $\mathrm{Mn}$ & $\mathrm{Fe}$ \\
\hline Conc. (mg/L) & 4168 & 1265 & 505 & 575 & 217 & $\mathrm{nd}$ & 5 & 6 & 85 & $\mathrm{nd}$ \\
Recovery (\%) & 97.4 & 93.8 & 94.8 & 96.2 & 99.9 & $\mathrm{nd}$ & 0.3 & 1.3 & 9.7 & nd \\
\hline
\end{tabular}

Table 7 Leach recovery under optimal conditions in experiment R10 the economically valuable REE. The equipment must resist strong acid, and the evolving gases $\left(\mathrm{SO}_{2}\right.$ and $\left.\mathrm{SO}_{3}\right)$ must be scrubbed from the vent and recycled as sulfuric acid.

\section{Conclusion}

Sulfation, selective roasting and water leaching is shown to be a viable option for separation of REEs from cobalt and nickel present in the cathode and anode materials of $\mathrm{NiMH}$ HEV batteries. Both the amount of acid and the acid concentration are important for achieving an efficient sulfation of the material. When the concentration of acid is high $(\geq 10 \mathrm{~mol} / \mathrm{L})$ or the roasting temperature is high $(\geq$ $900{ }^{\circ} \mathrm{C}$ ), the recovery of REE decreases due to the formation of REE oxysulfates that will remain in the solid phase together with $\mathrm{Ni}$ and $\mathrm{Co}$ in the water-leaching step. The optimal sulfuric acid concentration in the sulfation step was determined to be $8 \mathrm{~mol} / \mathrm{L}$ for a solid-to-liquid ratio of $1 / 5$. The optimal condition for the roasting step was keeping the temperature at $850{ }^{\circ} \mathrm{C}$ for $2 \mathrm{~h}$. Under these conditions $\mathrm{Ni}$ and $\mathrm{Co}$ turn into oxides while the REE remain in sulfate form. The REE sulfates are easily leached by water to obtain a slightly acidic relatively pure aqueous phase containing the REE suitable for further processing. The total recovery of rare earths from the anode and 


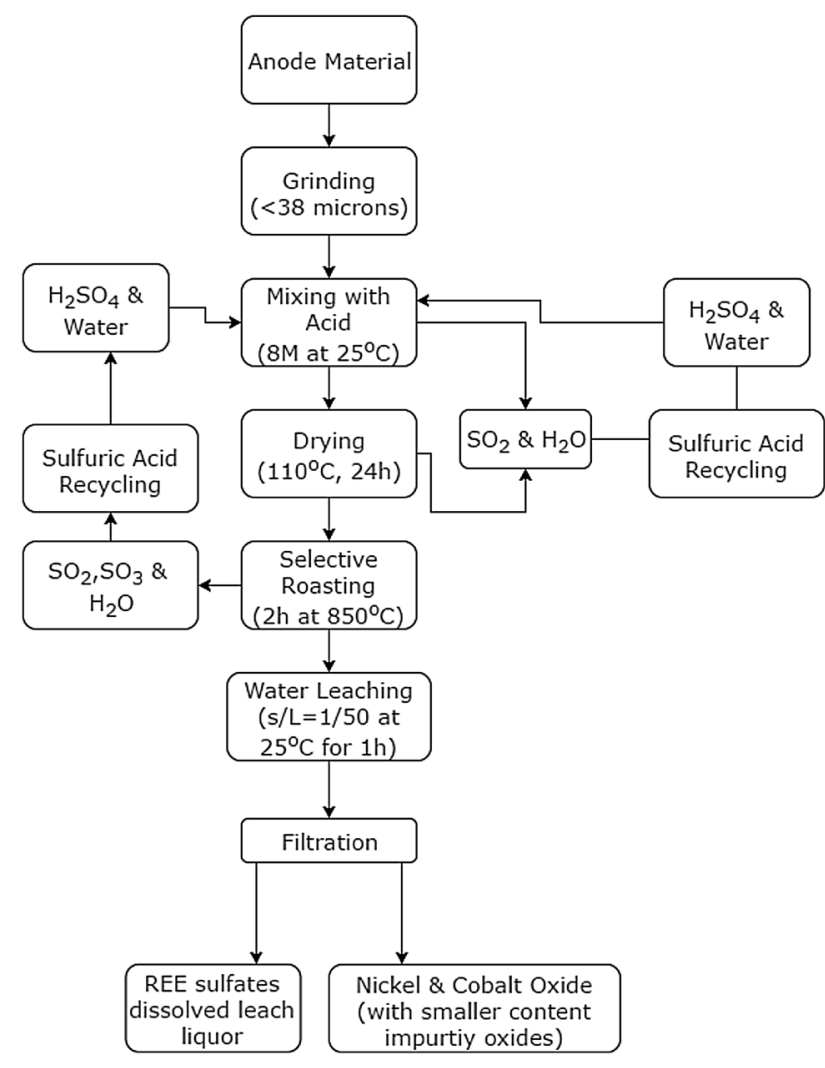

Fig. 8 Flowsheet of separation of REEs from HEV battery active material via selective roasting and water leaching under optimal conditions (color figure online)

cathode mixture was $96 \%$. At the optimal conditions negligible amounts of nickel and cobalt appeared in the REE stream.

Acknowledgements The authors would like to acknowledge the Swedish Energy Agency (Energimyndigheten) for funding the project (nr 37724-1) and Chalmers University of Technology, Department of Chemistry and Chemical Engineering for supplying the battery modules.

Open Access This article is distributed under the terms of the Creative Commons Attribution 4.0 International License (http://crea tivecommons.org/licenses/by/4.0/), which permits unrestricted use, distribution, and reproduction in any medium, provided you give appropriate credit to the original author(s) and the source, provide a link to the Creative Commons license, and indicate if changes were made.

\section{References}

1. European Commission (2010). Critical raw materials for the EU. Report of the ad-hoc working group on defining critical raw materials. European Commission, Raw Materials Supply Group, 30 July 2010, pp 85

2. European Commission Directive 2006/66/EC: Directive 2006/66/ EC of the European Parliament and of the council of 6 September 2006 on batteries and accumulators and waste batteries and accumulators and repealing Directive 91/157/EEC. OJ, L 266 26/09/2006, pp 1-14

3. Al-Thyabat S, Nakamura T, Shibata E, Iizuka A (2013) Adaptation of minerals processing operations for lithium-ion ( $\mathrm{LiBs}$ ) and nickel metal hydride (NiMH) batteries recycling: critical review. Miner Eng 45:4-17. https://doi.org/10.1016/j.mineng. 2012.12.005

4. Bernardes AM, Espinosa DCR, Tenório JAS (2004) Recycling of batteries: a review of current processes and technologies. J Power Sources 130(1-2):291-298. https://doi.org/10.1016/j.jpowsour. 2003.12.026

5. Bertuol DA, Bernardes AM, Tenório JAS (2009) Spent NiMH batteries - the role of selective precipitation in the recovery of valuable metals. J Power Sources 193(2):914-923. https://doi. org/10.1016/j.jpowsour.2009.05.014

6. Müller T, Friedrich B (2006) Development of a recycling process for nickel-metal hydride batteries. $J$ Power Sources 158(2):1498-1509. https://doi.org/10.1016/j.jpowsour.2005.10. 046

7. Pietrelli L, Bellomo B, Fontana D, Montereali M (2005) Characterization and leaching of $\mathrm{NiCd}$ and $\mathrm{NiMH}$ spent batteries for the recovery of metals. Waste Manag 25(2):221-226. https://doi. org/10.1016/j.wasman.2004.12.013

8. Espinosa DCR, Bernardes AM, Tenório JAS (2004) An overview on the current processes for the recycling of batteries. J Power Sources 135(1-2):311-319. https://doi.org/10.1016/j.jpowsour. 2004.03.083

9. Gharabaghi M, Irannajad M, Azadmehr AR (2013) Leaching kinetics of nickel extraction from hazardous waste by sulphuric acid and optimization dissolution conditions. Chem Eng Res Des 91(2):325-331. https://doi.org/10.1016/j.cherd.2012.11.016

10. Larsson K, Ekberg C, Odegaard-Jensen A (2013) Dissolution and characterization of HEV NiMH batteries. Waste Manag 33(3):689-698. https://doi.org/10.1016/j.wasman.2012.06.001

11. Meshram P, Pandey BD, Mankhand TR (2015) Leaching of base metals from spent $\mathrm{Ni}$-metal hydride batteries with emphasis on kinetics and characterization. Hydrometallurgy 158:172-179. https://doi.org/10.1016/j.hydromet.2015.10.028

12. Meshram P, Pandey BD, Mankhand TR (2016) Process optimization and kinetics for leaching of rare earth metals from the spent Ni-metal hydride batteries. Waste Manag 51:196-203. https://doi.org/10.1016/j.wasman.2015.12.018

13. Nan J, Han D, Yang M, Cui M, Hou X (2006) Recovery of metal values from a mixture of spent lithium-ion batteries and nickelmetal hydride batteries. Hydrometallurgy 84(1-2):75-80. https:// doi.org/10.1016/j.hydromet.2006.03.059

14. Pietrelli L, Bellomo B, Fontana D, Montereali MR (2002) Rare earths recovery from NiMH spent batteries. Hydrometallurgy 66(1-3):135-139. https://doi.org/10.1016/S0304-386X(02)00107-X

15. Rodrigues LEOC, Mansur MB (2010) Hydrometallurgical separation of rare earth elements, cobalt and nickel from spent nickelmetal-hydride batteries. J Power Sources 195(11):3735-3741. https://doi.org/10.1016/j.jpowsour.2009.12.071

16. Zhang P, Yokoyama T, Itabashi O, Wakui Y, Suzuki TM, Inoue K (1998) Hydrometallurgical process for recovery of metal values from spent nickel-metal hydride secondary batteries. Hydrometallurgy 50(1):61-75. https://doi.org/10.1016/S0304386X(98)00046-2

17. Fernandes A, Afonso JC, Dutra AJB (2013) Separation of nickel(II), cobalt(II) and lanthanides from spent Ni-MH batteries by hydrochloric acid leaching, solvent extraction and precipitation. Hydrometallurgy 133:37-43. https://doi.org/10.1016/j.hydromet. 2012.11.017

18. Innocenzi V, Vegliò F (2012) Recovery of rare earths and base metals from spent nickel-metal hydride batteries by sequential sulphuric acid leaching and selective precipitations. J Power 
Sources 211:184-191. https://doi.org/10.1016/j.jpowsour.2012. 03.064

19. Larsson K, Ekberg C, Ødegaard-Jensen A (2012) Using Cyanex 923 for selective extraction in a high concentration chloride medium on nickel metal hydride battery waste. Hydrometallurgy 129-130:35-42. https://doi.org/10.1016/j.hydromet.2012.08.011

20. Mubarok MZ, Lieberto J (2013) Precipitation of Nickel Hydroxide from Simulated and Atmospheric-leach Solution of Nickel Laterite Ore. Procedia Earth Planet Sci 6:457-464. https:// doi.org/10.1016/j.proeps.2013.01.060

21. Yang X, Zhang J, Fang X (2014) Rare earth element recycling from waste nickel-metal hydride batteries. J Hazard Mater 279:384-388. https://doi.org/10.1016/j.jhazmat.2014.07.027

22. Zhang P, Yokoyama T, Itabashi O, Wakui Y, Suzuki TM, Inoue K (1999) Recovery of metal values from spent nickel-metal hydride rechargeable batteries. J Power Sources 77(2):116-122. https://doi.org/10.1016/S0378-7753(98)00182-7

23. Feng X-L, Long Z-Q, Cui D-L, Wang L-S, Huang X-W, Zhang G-C (2013) Kinetics of rare earth leaching from roasted ore of bastnaesite with sulfuric acid. Trans Nonferr Met Soc China 23(3):849-854. https://doi.org/10.1016/S1003-6326(13)62538-8

24. Tang K, Ciftja A, van der Eijk C, Wilson S, Tranell G (2013) Recycling of the rare earth oxides from spent rechargable batteries using waste metallurgical slags. J Min Metall Sect B Metall 49(2):233-236. https://doi.org/10.2298/jmmb120808004t

25. Yang Z, Li H-Y, Yin X-C, Yan Z-M, Yan X-M, Xie B (2014) Leaching kinetics of calcification roasted vanadium slag with high $\mathrm{CaO}$ content by sulfuric acid. Int $\mathrm{J}$ Miner Process 133:105-111. https://doi.org/10.1016/j.minpro.2014.10.011

26. Yu D, Utigard TA, Barati M (2014) Fluidized bed selective oxidation-sulfation roasting of nickel sulfide concentrate: part I. Oxidation roasting. Metall Mater Trans B 45(2):653-661. https:// doi.org/10.1007/s11663-013-9958-x

27. Yu D, Utigard TA, Barati M (2014) Fluidized bed selective oxidation-sulfation roasting of nickel sulfide concentrate: part II. Sulfation roasting. Metall Mater Trans B 45(2):662-674. https:// doi.org/10.1007/s11663-013-9959-9

28. Guo XY, Li D, Park KH, Tian QH, Wu Z (2009) Leaching behavior of metals from a limonitic nickel laterite using a sulfation-roasting-leaching process. Hydrometallurgy 99(3-4):144-150. https://doi.org/10.1016/j.hydromet.2009.07.012

29. You ZX, Li GH, Zhang YB, Peng ZW, Jiang T (2015) Extraction of manganese from iron rich $\mathrm{MnO} 2$ ores via selective sulfation roasting with $\mathrm{SO} 2$ followed by water leaching. Hydrometallurgy 156:225-231. https://doi.org/10.1016/j.hydromet.2015.05.017

30. Borra CR, Mermans J, Blanpain B, Pontikes Y, Binnemans K, Van Gerven $T$ (2016) Selective recovery of rare earths from bauxite residue by combination of sulfation, roasting and leaching. Miner Eng 92:151-159. https://doi.org/10.1016/j.mineng. 2016.03.002

31. Önal M, Borra C, Guo M, Blanpain B, Van Gerven T (2015) Recycling of $\mathrm{NdFeB}$ magnets using sulfation, selective roasting, and water leaching. J Sustain Metall 1(3):199-215. https://doi. org/10.1007/s40831-015-0021-9

32. Korkmaz K, Forsberg KM, Alemrajabi M, Rasmuson ÅC (2016) Sustainable hydrometallurgical recovery of valuable elements from spent nickel-metal hydride HEV batteries. In: IMPC 2016: XXVIII International Mineral Processing Congress Proceedings

33. Pandher R, Thomas S, Yu D, Barati M, Utigard T (2011) Sulfate formation and decomposition of nickel concentrates. Metall
Mater Trans B 42(2):291-299. https://doi.org/10.1007/s11663010-9466-1

34. Pelovski Y, Petkova V (1997) Mechanism and kinetics of inorganic sulphates decomposition. J Therm Anal 49(3):1227-1241. https://doi.org/10.1007/bf01983679

35. Poston JA, Siriwardane RV, Fisher EP, Miltz AL (2003) Thermal decomposition of the rare earth sulfates of cerium(III), cerium(IV), lanthanum(III) and samarium(III). Appl Surf Sci 214(1-4):83-102. https://doi.org/10.1016/s0169-4332(03)003581

36. Straszko J, Możejko J, Olszak-Humienik M (1995) Kinetics of thermal decomposition of nickel sulfate hexahydrate. J Therm Anal 45(5):1109-1116. https://doi.org/10.1007/bf02547483

37. Straszko J, Olszak-Humienik M, Możejko J (2000) Study of the mechanism and kinetic parameters of the thermal decomposition of cobalt sulphate hexahydrate. $J$ Therm Anal Calorim 59(3):935-942. https://doi.org/10.1023/a:1010186628054

38. Tomaszewicz E, Kotfica M (2004) Mechanism and kinetics of thermal decomposition of nickel(II) sulfate(VI) hexahydrate. J Therm Anal Calorim 77(1):25-31. https://doi.org/10.1023/B: JTAN.0000033184.32714.7f

39. Lide DR (2004) CRC handbook of chemistry and physics. CRC Press, New York

40. Lokshin EP, Tareeva OA, Ivlev KG, Kashulina TG (2005) Solubility of double alkali metal $(\mathrm{Na}, \mathrm{K})$ rare-earth $(\mathrm{La}, \mathrm{Ce})$ sulfates in sulfuric-phosphoric acid solutions at $20^{\circ} \mathrm{C}$. Russ J Appl Chem 78(7):1058-1063. https://doi.org/10.1007/s11167-005-0449-y

41. The National Physical Laboratory (1995) 3.2 Properties of inorganic compounds. Tables of physical \& chemical constants (16th edition 1995). 2.1.4 Hygrometry. Kaye \& Laby Online. Version 1.0 (2005) from http://www.kayelaby.npl.co.uk/chemistry/3_2/3 2.html

42. Dixini PVM, Celante VG, Lelis MFF, Freitas MBJG (2014) Recycling of the anode from spent Ni-MH batteries for synthesis of the lanthanide oxysulfide/oxysulfate compounds used in an oxygen storage and release system. J Power Sources 260:163-168. https://doi.org/10.1016/j.jpowsour.2014.03.006

43. Patnaik P (2002) Handbook of inorganic chemicals. McGrawHill, New York

44. Todorovsky DS, Milanova MM, Minkova NL, Balarev C (1993) Solubility of some lanthanide sulfates in polycomponent systems containing H2SO4. Monatshefte für Chemie (Chem Mon) 124(6-7):673-679. https://doi.org/10.1007/BF00817302

45. Niinistö L, Saikkonen P, Sonninen R (1982) Thermal decomposition of rare earth sulfate and selenate hydrates. In: McCarthy GJ, Silber HB, Rhyne JJ, Kalina FM (eds) The rare earths in modern science and technology, vol 3. Springer, Boston, pp 257-263

46. Nathans MW, Wendlandt WW (1962) The thermal decomposition of the rare-earth sulphates. J Inorg Nucl Chem. https://doi. org/10.1016/0022-1902(62)80108-0

47. Wendlandt WW (1958) The thermal decomposition of yttrium and the rare earth metal sulphate hydrates. J Inorg Nucl Chem 7(1):51-54. https://doi.org/10.1016/0022-1902(58)80026-3

48. Kolta GA, Askar MH (1975) Thermal decomposition of some metal sulphates. Thermochim Acta 11(1):65-72. https://doi.org/ 10.1016/0040-6031(75)80038-4

49. Tagawa H (1984) Thermal decomposition temperatures of metal sulfates. Thermochim Acta 80(1):23-33. https://doi.org/10.1016/ 0040-6031(84)87181-6 